\title{
Addition of cell wall degrading enzyme and wheat bran on fermentation characteristics and in vitro gas production of ensiled rice straw
}

\author{
J.-M. Lv ${ }^{1}$, W.-L. Hu, and J.-X. Liu ${ }^{2}$ \\ College of Animal Sciences, Zhejiang University \\ 310029, Hangzhou, China
}

(Received 8 August 2004; revised version 1 March 2005; accepted 18 March 2005)

\begin{abstract}
A two way factorial experiment was designed to study the technique aspects of ensiling rice straw (RS) mixed with Strawzyme (an experimental preparation of cell-wall degrading enzymes) and wheat bran (WB). The WB was added at levels of $0,3,6$ or $9 \%$ (fresh basis), respectively, and the RS was untreated (C-0, C-3, C-6 and C-9), or treated with Strawzyme at level of $1300 \mathrm{~g} / \mathrm{t} \mathrm{DM}$ (T-0, T-3, T-6 and T-9). Addition of WB improved the fermentation quality and nutritive value of RS silage. The $\mathrm{pH}$ value, percentage of ammonia $\mathrm{N}$ in total $\mathrm{N}$ and butyrate content were decreased, and lactate content and in vitro gas production (GP) increased with the increasing levels of WB. Enzyme treatment decreased the neutral detergent fibre, $\mathrm{pH}$, ammonia- $\mathrm{N}$ and butyrate, and increased lactate and in vitro GP. There were significant interaction effects on $\mathrm{pH}$, lactate and butyrate content between enzyme and WB. Therefore the silages in T- 6 and T-9 showed good quality with lowest $\mathrm{pH}$ and highest lactate as well as no any butyrate. Proportion of ammonia $\mathrm{N}$ of total $\mathrm{N}$ was decreased by 37.9 or $15.5 \%$, and the lactic acid was increased by 67.8 or $5.7 \%$, respectively, when Strawzyme plus 6 or $9 \%$ WB was added. It can be concluded that combination of Strawzyme with WB was more effective in the improvement of RS silage quality than addition of WB alone.
\end{abstract}

KEY WORDS: rice straw silage, enzyme, fermentation, wheat bran, in vitro gas production

\section{INTRODUCTION}

Rice straw (RS) is a common byproduct of rice production in China, where 188 million tonnes are produced annually, but only a few of this byproduct is used

\footnotetext{
${ }^{1}$ Present address: Laboratory Animal Research Center, Zhejiang College of Traditional Chinese Medicine, 310053, Hangzhou, China. E-mail: ljmkiddy@sina.com

${ }^{2}$ Corresponding author: e-mail: liujx@zju.edu.cn
} 
as feedstuff for ruminants (Guo et al., 2002). It is necessary to find a good way to take advantage of RS resources.

An ideal material for preservation as silage should contain an applicable content of DM $(>20 \%)$ and an adequate level $(>10 \% \mathrm{DM})$ of fermentable substrate in form of water soluble carbohydrate (WSC) (McDonald et al., 1991). Due to the low level of WSC in raw RS, it is difficult to prepare RS silage of good quality without additives. Due to its effects on hydrolysis of fibrous materials, cell wall degrading enzymes have been widely used to improve the fermentation characteristics of silage during the last two decades (Setälä, 1989; Hoffman et al., 1995), but there are few reports about straw silage treated with enzyme (Shi et al., 1998). On the other hand, wheat bran (WB) may increase supply of WSC to those materials that are not easily ensiled alone such as straws with low WSC. It has been shown that addition of WB in astragalus silage and bamboo shoot shell silage may obtain satisfactory results (Fang et al., 1996; Liu et al., 2001).

The objectives of this study were to investigate the effects of cell wall degrading enzyme and wheat bran on fermentation characteristics and in vitro gas production (GP) of ensiled rice straw.

\section{MATERIAL AND METHODS}

Fresh rice straw (RS) and wheat bran (WB) were obtained from the farm of Zhejiang University. The enzyme preparation named Strawzyme was supplied by Microbiology Institute, Zhejiang Academy of Agricultural Science. Strawzyme contains cellulase $(3500 \mathrm{IU} / \mathrm{g})$ and xylanase $(450 \mathrm{IU} / \mathrm{g})$. One unit of cellulase activity (FPA) would liberate $1 \mu \mathrm{g}$ of glucose from filter paper in $1 \mathrm{~min}$ at $\mathrm{pH}$ 4.2 at $50^{\circ} \mathrm{C}$, and one unit of xylanase activity would liberate $1 \mu \mathrm{mol}$ of xylose from xylan in $1 \mathrm{~min}$ at $50^{\circ} \mathrm{C}$. Fresh RS was chopped into $5-10 \mathrm{~mm}$ pieces using a harvester chopper before ensiling.

\section{Experimental design}

A two-way factorial trial (WB and enzyme) was designed. The WB was added at levels of $0,3,6$ and $9 \%$ (fresh basis), respectively, to RS that was untreated (C-0, C-3, C-6 and C-9) or treated with Strawzyme at level of $1300 \mathrm{~g} / \mathrm{t}$ DM (T$0, \mathrm{~T}-3, \mathrm{~T}-6$ and T-9). Materials for each treatment were ensiled in triplicate in experimental silos with capacity of $5 \mathrm{~L}$. Contents of dry matter (DM) in the mixed materials were adjusted to about $20 \%$. Strawzyme was dissolved in water and the enzyme solution was sprayed onto the mixed materials. The silos were opened 40 days after ensiling. 


\section{Chemical analysis}

Representative samples of experimental feeds were taken for later analysis of chemical composition. Silages were evaluated by subjective criteria such as colour, smell, and texture immediately when the experimental silos were opened. Representative samples were taken for later analysis.

Dry matter (DM) and crude protein (CP) were determined according to AOAC (1990), and neutral detergent fibre (NDF) by the method of Van Soest et al. (1992) with addition of sodium sulphite in detergent. DM content of silages was corrected for losses of volatile substances by the equation: $\mathrm{DM}(\%)=\mathrm{DM}_{\mathrm{NC}}(\%) \times[100+$ $\left.\left(15.28-0.371 \times \mathrm{DM}_{\mathrm{NC}}(\%)\right)\right] / 100$, where subscript $\mathrm{NC}$ indicates not corrected (De Boever et al., 1993). Residual ash was not determined and eliminated from NDF. The WSC content was determined according to the method of Dubois et al. (1956). Silage was extracted with distilled water (silage:water $=1: 10, \mathrm{w} / \mathrm{v}$ ), and the supernatant was used for determination of $\mathrm{pH}$, ammonia- $\mathrm{N}$ and organic acids (lactate, acetate, propionate and butyrate). Ammonia-N concentration was determined by steam distillation into boric acid and titration with dilute hydrochloric acid (10 mmol/L) (AOAC, 1990). Organic acids were determined by gas chromatograph (Model SP-502, Hitachi). Samples were injected into a 2 $\mathrm{m} \times 4 \mathrm{~mm}$ stainless steel column packed with Porapak Q. Temperatures of the injector/detector and column were $260 / 260$ and $215^{\circ} \mathrm{C}$, respectively. Nitrogen gas was used as a carrier at a flow rate of $65 \mathrm{ml} / \mathrm{min}$, and air and $\mathrm{H}_{2}$ flowed at a rate of 550 and $55 \mathrm{ml} / \mathrm{min}$, respectively. The materials before and after treatments were weighed and DM recovery was calculated.

\section{In vitro gas production}

The GP was determined according to Menke and Steingass (1988). About $200 \mathrm{mg}$ silage sample (dried at $105^{\circ} \mathrm{C}$ and ground through $1 \mathrm{~mm}$ sieve) was accurately weighed into $100-\mathrm{ml}$ glass syringes fitted with plungers. Syringes were filled with $30 \mathrm{ml}$ medium consisting of $10 \mathrm{ml}$ rumen fluid and $20 \mathrm{ml}$ buffer solution. Rumen fluid was collected from two rumen-fistulated sheep, which were fed on the diet ( $70 \%$ ammoniated RS, 25\% concentrate mixture and 5\% oilseed cake) at 1.3 times maintenance. Three blanks syringes containing $30 \mathrm{ml}$ medium only were included. The syringes were placed in a water bath $\left(39^{\circ} \mathrm{C}\right)$ with shaking bed. The gas volume was recorded after $2,4,6,9,12,24,36,48$ and $96 \mathrm{~h}$ incubation. The data were then fitted to the equation: $\mathrm{GP}=a+b\left(1-\mathrm{e}^{-c t}\right)$ (Ørskov and McDonald, 1979), where $a, b$ and $c$ are constants and GP is the gas production from the substrate at time t. 


\section{Statistical analysis}

Data were analysed by a two-way factorial analysis of variance (Steel and Torrie, 1980), and comparisons of means among treatments were made using the least significant difference procedure when significant F-test for the main effect was found.

\section{RESULTS}

Content of DM of the RS and WB were 31.4 and $86.3 \%$, respectively. The CP, NDF and WSC in RS (on DM basis) were 8.1, 74.2 and 3.5\%, and those in WB were $17.9,52.3$ and $8.3 \%$, respectively.

Addition of WB increased CP and decreased NDF content $(\mathrm{P}<0.01)$, and there was a dose-dependant manner with the increasing level of WB (Table 1). The NDF content in enzyme-treated silages was significantly lower $(\mathrm{P}<0.01)$ than in the untreated. All treatments had little effect on DM recovery.

TABLE 1

Chemical composition and dry matter recovery of rice straw mixed silages

\begin{tabular}{|c|c|c|c|c|c|c|c|c|c|c|c|c|}
\hline \multirow{2}{*}{$\begin{array}{l}\text { Enzyme, g/t DM } \\
\text { Wheat bran, \% }\end{array}$} & \multicolumn{4}{|c|}{$0(\mathrm{C})$} & \multicolumn{4}{|c|}{$1300(\mathrm{~T})$} & \multirow{2}{*}{ SEM } & \multicolumn{3}{|c|}{ Significance $^{a}$} \\
\hline & 0 & 3 & 6 & 9 & 0 & 3 & 6 & 9 & & $E$ & $\mathrm{~W}$ & $\mathrm{E} \times \mathrm{W}$ \\
\hline$\overline{\mathrm{DM}, \%}$ & 17.6 & 17.5 & 17.0 & 19.1 & 17.2 & 16.7 & 17.8 & 19.4 & 0.43 & NS & $* * *$ & NS \\
\hline NDF, \%DM & 71.7 & 70.5 & 68.6 & 67.8 & 69.7 & 68.9 & 65.3 & 62.5 & 1.44 & $* *$ & $* *$ & NS \\
\hline $\mathrm{CP}, \% \mathrm{DM}$ & 7.9 & 8.6 & 9.0 & 9.9 & 7.7 & 8.4 & 9.3 & 10.9 & 0.21 & NS & $* * *$ & NS \\
\hline DM recovery, \% & 87.5 & 84.3 & 81.6 & 85.6 & 83.1 & 82.0 & 85.1 & 87.6 & 1.71 & NS & NS & NS \\
\hline
\end{tabular}

${ }^{a} \mathrm{E}$ - effect of enzyme, $\mathrm{W}$ - effect of wheat bran, $\mathrm{E} \times \mathrm{W}$ - interaction effect between enzyme and wheat bran

$* \mathrm{P}<0.05 ; * * \mathrm{P}<0.01 ; * * * \mathrm{P}<0.001 ; \mathrm{NS}-$ not significant

The $\mathrm{pH}$ was lower in the enzyme-treated silages than in the untreated and declined with the adding levels of WB $(\mathrm{P}<0.01$; Table 2$)$. There was interactive effect on the $\mathrm{pH}$ of rice straw silage between enzyme treatment and WB addition. Ammonia $\mathrm{N}$ decreased with the increasing WB level $(\mathrm{P}<0.01)$ and had higher value in the treated silages than in the untreated.

Addition of WB increased lactate, and decreased acetate, propionate and butyrate content $(\mathrm{P}<0.01)$. Enzyme treatment increased lactate and decreased butyrate content $(\mathrm{P}<0.01)$, but did not affect acetate and propionate content by the enzyme treatment $(\mathrm{P}>0.05)$. There were significant interactive effects on the individual acids between enzyme and WB. There was plenty of butyrate in both 0 and 3\% WB for $\mathrm{C}$ and $\mathrm{T}$, but butyrate was not detected at all in T-6 and T-9. 
The potential GP $(a+b)$ was increased $(\mathrm{P}<0.01)$ with enzyme treatment or WB addition (Table 3), thus its value in T-9 was highest, with $55.6 \%$ higher than that in $\mathrm{C}-0$. The GP at $48 \mathrm{~h}$ showed the similar trend to the potential GP. However, the fractional degradation rate $c$ was not influenced by enzyme, but increased with the inclusion level of WB $(\mathrm{P}<0.01)$.

TABLE 2

Ratio of ammonia- $\mathrm{N}$ to total $\mathrm{N}\left(\mathrm{NH}_{3}-\mathrm{N} / \mathrm{TN}\right), \mathrm{pH}$ value and organic acid contents in rice straw mixed silages

\begin{tabular}{|c|c|c|c|c|c|c|c|c|c|c|c|c|}
\hline \multirow{2}{*}{$\begin{array}{l}\text { Enzyme, g/t DM } \\
\text { Wheat bran, \% }\end{array}$} & \multicolumn{4}{|c|}{$0(\mathrm{C})$} & \multicolumn{4}{|c|}{$1300(\mathrm{~T})$} & \multicolumn{4}{|c|}{ Significance $^{a}$} \\
\hline & 0 & 3 & 6 & 9 & 0 & 3 & 6 & 9 & & $\mathrm{E}$ & W & $\mathrm{E} \times \mathrm{W}$ \\
\hline $\mathrm{pH}$ & 4.90 & 4.85 & 4.72 & 4.21 & 4.84 & 4.83 & 4.21 & 4.19 & 0.07 & $* *$ & $* * *$ & $* *$ \\
\hline $\mathrm{NH}_{3}-\mathrm{N} / \mathrm{TN}, \%$ & 30.9 & 28.9 & 13.0 & 10.3 & 28.8 & 27.3 & 8.1 & 8.7 & 1.53 & $*$ & $* * *$ & NS \\
\hline \multicolumn{13}{|c|}{ Organic acids, g/kg DM } \\
\hline lactate & $\begin{array}{r}3.7 \\
(5)^{\mathrm{b}}\end{array}$ & $\begin{array}{l}6.3 \\
(8)\end{array}$ & $\begin{array}{l}19.6 \\
(30)\end{array}$ & $\begin{array}{l}39.3 \\
(52)\end{array}$ & $\begin{array}{l}4.4 \\
(5)\end{array}$ & $\begin{array}{l}6.6 \\
(8)\end{array}$ & $\begin{array}{l}32.9 \\
(63)\end{array}$ & $\begin{array}{l}41.6 \\
(61)\end{array}$ & 1.52 & $* * *$ & $* * *$ & $* * *$ \\
\hline acetate & $\begin{array}{l}41.1 \\
(56)\end{array}$ & $\begin{array}{l}43.1 \\
(54)\end{array}$ & $\begin{array}{l}29.7 \\
(46)\end{array}$ & $\begin{array}{l}22.7 \\
(30)\end{array}$ & $\begin{array}{l}51.1 \\
(57)\end{array}$ & $\begin{array}{l}51.1 \\
(61)\end{array}$ & $\begin{array}{l}19.2 \\
(37)\end{array}$ & $\begin{array}{l}26.8 \\
(39)\end{array}$ & 2.70 & NS & $* * *$ & * \\
\hline propionate & $\begin{array}{l}2.9 \\
(4)\end{array}$ & $\begin{array}{l}1.6 \\
(2)\end{array}$ & $\begin{array}{l}1.3 \\
(2)\end{array}$ & $\begin{array}{l}0.7 \\
(1)\end{array}$ & $\begin{array}{l}3.8 \\
(4)\end{array}$ & $\begin{array}{l}2.6 \\
(3)\end{array}$ & 0.0 & 0.0 & 0.23 & NS & $* *$ & $* * *$ \\
\hline butyrate & $\begin{array}{l}25.7 \\
(35)\end{array}$ & $\begin{array}{l}29.3 \\
(36)\end{array}$ & $\begin{array}{l}14.0 \\
(22)\end{array}$ & $\begin{array}{l}12.8 \\
(17)\end{array}$ & $\begin{array}{l}30.8 \\
(34)\end{array}$ & $\begin{array}{l}23.8 \\
(28)\end{array}$ & 0.0 & 0.0 & 1.89 & $* * *$ & $* * *$ & $* * *$ \\
\hline total & 73.4 & 80.3 & 64.4 & 75.5 & 90.1 & 84.1 & 52.1 & 68.4 & 7.06 & NS & $* *$ & NS \\
\hline
\end{tabular}

${ }^{a} \mathrm{E}$ - effect of enzyme; W - effect of wheat bran; $\mathrm{E} \times \mathrm{W}$ - interaction effect

${ }^{*} \mathrm{P}<0.05 ; * * \mathrm{P}<0.01 ; * * * \mathrm{P}<0.001 ; \mathrm{NS}-$ not significant

${ }^{\mathrm{b}}$ figures in the parentheses indicate proportion of each organic acid to the total

TABLE 3

Parameters of in vitro gas test of rice straw mixed silages

\begin{tabular}{|c|c|c|c|c|c|c|c|c|c|c|c|c|}
\hline \multirow{2}{*}{$\begin{array}{l}\text { Enzyme, g/t DM } \\
\text { Wheat bran, \% }\end{array}$} & \multicolumn{4}{|c|}{$0(\mathrm{C})$} & \multicolumn{4}{|c|}{$1300(\mathrm{~T})$} & \multirow{2}{*}{ SEM } & \multicolumn{3}{|c|}{ Significance $^{\mathrm{a}}$} \\
\hline & 0 & 3 & 6 & 9 & 0 & 3 & 6 & 9 & & $\mathrm{E}$ & W & $\mathrm{E} \times \mathrm{W}$ \\
\hline \multicolumn{13}{|l|}{ Gas production } \\
\hline$a+b, \mathrm{ml}$ & 29.4 & 33.3 & 37.0 & 37.4 & 34.3 & 37.1 & 39.7 & 40.2 & 0.54 & $* * *$ & $* * *$ & NS \\
\hline$c, \mathrm{ml} / \mathrm{h}$ & 0.028 & 0.028 & 0.027 & 0.032 & 0.025 & 0.025 & 0.030 & 0.036 & 0.001 & NS & $* * *$ & NS \\
\hline$G P_{48}^{\mathrm{b}}, \mathrm{ml}$ & 21.4 & 24.0 & 26.7 & 29.1 & 23.5 & 25.6 & 30.6 & 33.3 & 0.66 & $* * *$ & $* * *$ & NS \\
\hline
\end{tabular}

${ }^{\mathrm{a}} \mathrm{E}$ - effect of enzyme; $\mathrm{W}$ - effect of wheat bran; $\mathrm{E} \times \mathrm{W}$ - interaction effect

${ }^{*} \mathrm{P}<0.05 ; * * \mathrm{P}<0.01 ; * * * \mathrm{P}<0.001 ; \mathrm{NS}$ - not significant

${ }^{\mathrm{b}} \mathrm{GP}_{48}$ - gas production at $48 \mathrm{~h}$ incubation 


\section{DISCUSSION}

The RS had very low content of WSC (3.5\%DM). If it is ensiled alone, the fermentation could be dominated by clostridium, which leads to high concentrate of ammonia-N and butyrate in the silage (McDonald et al., 1991). When the RS was ensiled without enzyme and WB or with little WB, the silages had a higher $\mathrm{pH}$, higher ammonia- $\mathrm{N}$, lower lactate and higher butyrate content, indicative of low quality.

With the increasing level of $\mathrm{WB}$, the $\mathrm{pH}$, ammonia-N and butyrate content dropped, and the lactate content increase gradually (Table 2). When the WB addition level reached $9 \%$, RS silage of good quality was obtained. These results suggest that WB could have increased the WSC content. Similar results have been observed when WB was added to astragalus silage (Fang et al., 1996) and bamboo shoot shell silage (Liu et al., 2001).

The technique of adding plant cell-wall degrading enzyme in silage may improve fermentation quality, as enzyme can degrade the cell wall of RS into WSC and thus increase the WSC content of the materials indirectly. Several successful results have been reported (Setälä, 1989; Hoffman et al., 1995; Ridla et al., 1997; Shi et al., 1998). In this study, addition of enzyme increased lactate content and lowered the NDF, $\mathrm{pH}$ and $\mathrm{NH}_{3}-\mathrm{N}$ content. This demonstrates that enzyme could break down the cellulose of RS, and produce more WSC, which could accelerate the lactic fermentation. However, even when enzyme was added, the quality of RS silage was not good at a low WB addition level (T-3), which may be because the WSC concentration in this silage was still too low to ensile successfully. Significant interaction effects existed on $\mathrm{pH}$ and all individual organic acids between enzyme and WB. Therefore, an excellent quality of silage could be obtained when the enzyme and 6 or $9 \%$ WB were added simultaneously. As 9\% WB addition level had no significant difference with $6 \% \mathrm{WB}$, it can be suggested that the enzyme may be effective when WB was added at a level above $6 \%$.

Addition of WB or treatment with Strawzyme increased potential GP and $G P_{48}$ values (Table 3), which mainly attributed to the decrease in NDF content of silages. The results obtained in this study indicated that adding Strawzyme and WB could improve not only the fermentation characteristics but also the nutritive value of RS silage. 


\section{CONCLUSIONS}

Rice straw with low content of WSC and high NDF content is not easily ensiled without additive. Addition with wheat bran could improve the fermentation quality and nutritive value of rice straw silage, while combination of Strawzyme with WB is more effective than addition of WB alone in the improvement of both rice straw silage quality and nutritive value.

\section{REFERENCES}

AOAC, 1990. Official Methods of Analysis, Association of Official Analytical Chemists. 15 Edition. Washington, DC

De Boever J.L., De Brabander D.L., De Smet A.M., Vanacker J.M., Boucque C.V., 1993. Evaluation of physical structure. 2. Maize silage. J. Dairy Sci. 76, 1624-1634

Dubois M., Gilles K.A., Hamilton J.K., Rebers P.A., Smith F., 1956. Colorimetric method for determination of sugars and related substances. Anal. Chem. 28, 350-356

Fang D.L., Zhang Y.T., Liu J.X., 1996. Study on the fermentation characteristics of Astragalus silage (in Chinese). J. Zhejiang Agr. Univ. 22, 168-171

Guo T.S., Sanchez M.D., Guo P.Y. (Editors), 2002. Animal Production Based on Crop Residues - Chinese Experiences. FAO Animal Production and Health. FAO, Rome, Paper No. 149, pp. $1-20$

Hoffman P.C., Welch B.D.A., Brehm N.M., 1995. Potential of enzyme mixtures to improve silage quality and lactation performance of dairy cattle. J. Prod. Agr. 8, 552-557

Liu J.X., Wang X.Q., Shi Z.Q., 2001. Addition of rice straw or/and wheat bran on composition, ruminal degradability and voluntary intake of bamboo shoot shell silage feed to sheep. Anim. Feed Sci. Tech. 91, 129-138

McDonald P., Henerson N., 1991. The Biochemistry of Silage. 2nd Edition. Chalcombe Publications (UK)

Menke K.H., Steingass H., 1988. Estimation of the energetic feed value obtained from chemical analysis and in vitro gas production using rumen fluid. Anim. Res. Develop. 28, 7-55

Ørskov E.R., McDonald I., 1979. The estimation of protein degradability in the rumen from incubation measurements weighted according to rate of passage. J. Agr. Sci. 92, 499-503

Ridla M., Uchida S., 1997. Effect of cellulose and brewers grains addition on the fermentation quality and nutritive value of barley straw silage. Asian-Austr. J. Anim. Sci. 10, 575-580

Setälä J., 1989. Enzyme in grass silage production. Food Biotechnol. 2, 211-225

Shi Z.Q., Liu J.X., Zhang J.H., 1998. Effect of an enzyme addition on fermentation characteristics and chemical composition of corn stover silage (in Chinese). J. Zhejiang Agr. Univ. 24, 653657

Steel R.D.G., Torrie, J.H., 1980. Principles and Procedures of Statistics. 2nd Edition. McGraw-Hill, New York, pp. 197-194, 363-372

Van Soest P.J., Robertson J.B., Lewis B.A., 1991. Methods for dietary fibre neutral, and non-starch polysaccharides in relation to animal nutrition. J. Dairy Sci. 74, 3583-3597 


\section{STRESZCZENIE}

\section{Wpływ dodatku enzymu rozkładającego błony komórkowe oraz otrąb pszennych na profil fermentacji i produkcję gazu in vitro zakiszonej słomy ryżowej}

W dwuczynnikowym doświadczeniu badano techniczne zagadnienia zakiszania słomy ryżowej (RS) zmieszanej z Strawzyme (doświadczalnego preparatu zawierającego enzymy rozkładające błony komórkowe) i otrębami pszennymi (WB). Otręby dodawano w ilości 0, 3, 6 lub 9\%, a do RS nie dodawano (C-0, C-3, C-6 i C-9) lub dodawano Strawzyme w ilości 1300 g/t s.m. (T-0, T-3, T-6 i T-9). Dodatek WB poprawiał jakość fermentacji i wartość pokarmową kiszonki z RS. Wartość $\mathrm{pH}$, procentowy udział $\mathrm{N}-\mathrm{NH}_{3}$ w $\mathrm{N}$ całkowitym oraz zawartość kwasu masłowego zmniejszały się, a zawartość kwasu mlekowego oraz produkcja gazu (GP) in vitro zwiększały się w miarę zwiększania dodatku WB. Dodatek enzymu spowodował obniżenie zawartości NDF, $\mathrm{pH}, \mathrm{N}_{-} \mathrm{NH}_{3}$, kwasu masłowego, a zwiększył i GP in vitro. Stwierdzono istotną interakcję wpływu na pH oraz zawartość kwasów mlekowego i masłowego między enzymem i WB. Stąd kiszonki T-6 i T-9 były dobrej jakości o najniższym pH i większej zawartości kwasu mlekowego i braku masłowego. Udział

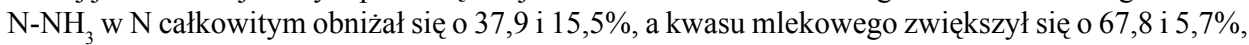
odpowiednio, przy dodatku Strawzyme plus 6 lub 9\% WB.

W podsumowaniu można stwierdzić, że kombinacja Strawzyme z WB efektywniej poprawia jakość kiszonki RS niż dodatek samych otrąb pszennych. 